\title{
TRI SVETE MARIJE U HRVATSKOJ PASIONSKOJ PUČKOJ KNJIŽEVNOSTI
}

\author{
Marko Dragić
}

Filozofski fakultet Sveučilišta u Splitu mdragic@ffst

\author{
UDK: 398.8(497.5):27-565.54 \\ 27-312.47Djevica Maria \\ 27-36Maria Magdalena,sancta \\ 27-36Maria Kleofina, sancta \\ 27-36Maria Jakovljeva, sancta \\ https://doi.org/10.34075/cs.56.1.2 \\ Izvorni znanstveni rad \\ Rad zaprimljen 7/2020.
}

\section{Sažetak}

$U$ radu se navodi $i$ interpretira dvadesetak tradicijskih pasionskih pjesama, i običaja u okviru kojih se te pjesme kazuju, a koje govore o Mariji Magdaleni, Mariji Jakovljevoj i Mariji Salomi, koje su s Blaženom Djevicom Marijom pratile Isusa na Golgotu, stajale uz Isusa raspetoga na križu. Kad je prošla subota, kupile su miomirise s kojima su htjele pomazati Isusa u grobu. Usput su razgovarale tko će otkotrljati veliki kamen s groba kako bi ga pomazale. Kad su došle grobu, vidjele su da je kamen s groba otkotrljan, a grob prazan. Ušle su u grob i vidjele su mladića zaogrnutoga bijelom haljinom koji sjedi zdesna. Uplašile su se, a anđeo (mladić) im je rekao da se ne plaše jer je Isus uskrsnuo. Mladić im je rekao da idu Isusovim učenicima Petru i Ivanu i reknu im da Isus ide u Galileju i ondje će ga njegovi učenici vidjeti. Marije su se uplašile, pobjegle od groba do Petra $i$ Ivana i obavijestile ih da je Isus uskrsnuo. Kadaje Marija Magdalena obavijestila Petra i Ivana, vratila se grobu, a kod groba joj se ukazao Isus Krist.

Pjesme u radu interpretiraju se $u$ kontekstu evanđelja i liturgije te u etnološkom $i$ antropološkom kontekstu. Te pjesme i molitve zapisivane su tijekom prethodne dvadeset dvije godine u nekim mjestima u Republici Hrvatskoj te Bosni i Hercegovini. Sve te pjesme imaju izniman estetski značaj i u suglasju su s evanđeljima.

Ključne riječi: Marija Magdalena, Marija Jakovljeva, Marija Saloma, muka Isusa Krista, Djevica Marija, uskrsnuće, grob Isusa Krista. 


\section{UVOD}

Iako je višeznačan pojam, za našu se svrhu, u književnosti, pod pojmom Pasija označuje se Isusova muka, od Posljednje večere do smrti na križu. Budući da je i vrijeme Isusova boravka u grobu također vrijeme šutnje, nije neobično, dapače, da pogotovo u pučkoj pobožnosti Pasija, odnosno Pasionske pobožnosti traju do uskrsnoga jutra. Pasija je trajno nadahnuće pučkim stvaraocima, i svim ostalim umjetnicima.

U hrvatskoj književnosti poznate su pučke pjesmarice s temom Pasije iz 14. i 15. stoljeća. U našem narodu nije rijetkost da još uvijek starije osobe pamte i kazuju tradicijske pasionske pjesme i molitve koje govore o trima svetim Marijama: Mariji Magdaleni, Mariji Salomi i Mariji Kleofini. Tri Marije su s Djevicom Marijom i drugim ženama i muškarcima pratile Isusa do Kalvarije, gdje je razapet na križu. Tri Marije i Djevica Marija stajale su pod križem. Tri Marije su u subotu krenule grobu noseći masti i pomasti kako bi Isusove rane namazale. Međutim grob je bio prazan. Isus je uskrsnuo.

U iločkom kraju bio je običaj da tri žene na Veliku subotu idu do tri križa moleći krunicu i druge molitve, ne razgovarajući međusobno niti s prolaznicima. Sastale bi se kod križa pred crkvom i mirno razišle.

Ovaj rad je nastao nakon dvadesetdvogodišnjega terenskoistraživačkog rada. Osim jedne, sve pjesme, molitve i običaji prvi put se objavljuju sada.

\section{TRI SVETE MARIJE}

U evanđeljima Mateja, Luke i Ivana piše da da su Isusa promatrale, pratile i posluživale mu kad je bio na Galileji i neke žene među kojima su bile Marija Magdalena, Marija Jakova Mlađega i Josipa i (Marija) Saloma (Mt 27,45-56; Lk 23,44-49; Iv 19,28-30).

Evanđelisti Matej, Marko i Luka pišu da su uz Isusov križ stajale Isusova majka i njezina sestra Marija Kleofina i Marija Magdalena. "(26) Kad Isus vidje majku i kraj nje učenika kojeg je ljubio, reče majci: ‘Ženo! Evo ti sina! Zatim reče učeniku: ‘Evo ti majke!' (27) I od toga časa uze je učenik k sebi“ (Mt 27,55-56; Mk 15,40-41; Lk 23,49).

Isus Krist je, riječima upućenim Ivanu evanđelistu, u posljednjim trenutcima pokazao kako se vrši četvrta Božja zapovijed o poštivanju roditelja i brizi za njih. ${ }^{1}$

1 Janko Oberški, Biblijska povijest staroga i novoga zavjeta. Marjan tisak. Split, 2005., 193. 


\subsection{Sveta Marija Magdalena}

Sveta Marija Magdalena jedna je od "zagonetnijih" biblijskih žena. Tradicija ju je izjednačavala sa ženom grešnicom koja je Isusu otrla noge svojim suzama, ali toj ženi doduše nigdje nije napisano ime. Poistovjećivanje s grešnicom vjerojatno dolazi od opisa $u$ evanđeljima gdje žene Isusu pomasti i kosom otiru noge. U Mateja i Marka ta je žena neimenovana i grešnica je, a u Ivana je vrlo precizno imenovana, Marija, sestra Martina i Lazarova. Ali i konteksti imaju razlika: sve se doduše odvija u Betaniji i pred Muku, ali kod Mateja i Marka u kući Šimuna Gubavca, a kod Ivana u kući Marte, Marije i Lazara. Nije onda teško zaključiti zbog čega su te dvije žene identitetski izjednačene. ${ }^{2}$

Nadalje, pučka tradicija, možda utemeljena na apokrifnim spisima, veli da je u Jeruzalemu bio neki bogati Židov Siro, koji je imao sina Lazara i kćeri Martu i Magdalenu. Nakon njegove smrti Lazaru su pripala mnoga imanja oko Jeruzalema, Marti u Betaniji, a Mariji je pripao grad Magdala i tako se ona prozva Magdalenom. U Jeruzalemu je Magdalena postala grešnica. Potom je Isus je iz nje istjerao sedam đavola (Mk 16,9). Zanimljivo je ipak da se u evanđeljima Marija Magdalena spominje samo u kontekstu uskrsnuća!

Svakako prema tradicijskoj predaji Marija ${ }^{3}$ Magdalena slušala je da neki prorok ide po Jeruzalemu i propovijeda. Krenula je poslušati ga. Kad ju je Isus gizdavu i slobodniju od drugih ugledao, upro je pogled u nju. Taj je božanski pogled upalio Magdalenino srce. Vratila se kući i počela plakati.

Posramljena, potražila je Isusa, stupila pred njega, suzama mu mijući noge i brišući ih vlasima svojim i zavjetnom mašću mažući, tražila oprost. Isus joj je oprostio "O ženo, praštaju se grijesi tvoji, pojdi u miru i već nemoj sagriševati. "4 Magdalena je ostala čvrsto držana i vezana u ljubavi Isukrstovoj, od koga je primila veliku milost te je dušu, silu i imanje na službu Njegovu i učenika Njegovih dala. Nalazimo je već u evanđeljima kao dio skupine koja prati Isusa: dok je Isus obilazio gradove i sela propovijedajući i navješ-

2 Istočni kršćani nikada Mariju Magdalenu nisu izjednačavali s grešnicom. Dapače, na temelju propovijedi Ivana Zlatoustoga Marija Magdalena je u istočnoj kršćanskoj tradiciji djevica, jedna od svetih mirofora, odnosno žena koje su došle pomazati Isusovo tijelo na uskrsno jutro.

3 Marija - hebrejski Mirjam, znači uzvišena, jaka, gospodarica, vidjelica (Anđelko Badurina, nav. dj., 393-394).

4 Bartol Kašić, Život s. Marije Mandaljene. Zbornik proze XVI. i XVII. stoljeća, priredio Jakša Ravlić. PSHK, knjiga 11, Zora i Matica hrvatska, Zagreb, 1972., str. 212. 
ćujući evanđelje o kraljevstvu Božjemu, s njim su bila dvanaestorica "i neke žene koje bijahu izliječene od zlih duhova i bolesti: Marija zvana Magdalena, iz koje bijaše izagnao sedam đavola; zatim Ivana, žena Herodova upravitelja Huze; Suzana i mnoge druge. One su im posluživale od svojih dobara" (Mt 11,16-19).

Pratila je Isusa dok su ga vodili na Kalvariju, bila je prisutna kad su Isusa razapinjali na križ, a u uskršnje jutro stajala je pred praznim Kristovim grobom. Isus Krist se prvoj ukazao Mariji Magdalenoj (Mk 16, 9).

Spoj biblijskih izvještaja zajedno s tradicijskim elementima složio je na ovakav način povijest ove, očito vrlo važne žene u prvoj kršćanskoj zajednici. Općenito o sudbini Marije Magdalene nemamo pouzdanih podataka. Vjerojatno je nakon smrti pokopana u Efezu. Bizantski car Lav VI. njezine relikvije dao je godine 899. prenijeti u Carigrad. ${ }^{5}$

O Mariji Magdaleni postoji legenda prema kojoj su Židovi nakon kamenovanja sv. Stjepana ${ }^{6}$ ostale učenike Isusove uhvatili i protjerali iz Jeruzalema: Lazara, Maksimina, koji je bio jedan od sedamdeset dva Isusova učenika, Celdonia, koji je slijep rođen te od Isusa ozdravljen, Magdalenu, Martu i Marcelu, koja je bila službenica Martina; njih šestero stavili su u barku bez vesala i pustili ih na morsku pučinu da ih vjetar potopi. Bog je s barkom vladao te je ona pristala u Marseilleu u Francuskoj. U tom je gradu živio Emilian, koji dugo vremena nije imao djece. Bio je poganin, a kada je slušao novu vjeru dozvao je (njih šestero) i rekao im da će, ako mu od Boga isprose milost da dobije porod, i on prigrliti novu vjeru. Magdalena je obećala moliti za njega. Njegova žena se nakon devet mjeseci porodila te su Emilian i sav Marseille prihvatili vjeru Kristovu. ${ }^{7}$

Potom je Lazar bio biskup od Marseillea, Maksimin od Axa, a Celdonio u Ingilteru, Marta je otišla u samostan s nekim djevojkama, a Magdalena u špilju, gdje je, prema kasnijim pučkim predajama koje su se posebno raširile u kasnom srednjem vijeku, provela trideset godina jedući samo travu i korijenje, a vlasi bjehu za odjeću tijela njezina. ${ }^{8}$ Neki pustinjak se primirio i vidio da mnoštvo anđela neku ženu k nebu uzdižu i nakon ure pjevajući opet na zemlju vraćaju. Pustinjak je pošao vidjeti čudo. Noge su mu drhtale od straha i, shvativši da je ondje skrovište Božje, prekriži se i zakriča govo-

Erhard Gorys, Leksikon svetaca. Naklada Slap. Jastrebarsko, 2003., 269.

Velika je vjerojatnoća da je to bilo 36. godine.

Bartol Kašić, nav. dj., 212.

Isto. 
reći: "Zaklinjem te Bogom živim koji si u toj spilji, kaži mi se. ${ }^{9}$ Iz špilje je začuo kako ga zove njegovim imenom, Prokopije. Bojažljivo se primaknuo špilji slušajući anđeoski glas koji ga je pitao o Mariji Magdaleni koja je nekad bila grješnica. Prokopije je odgovorio da je slušao o Magdaleni, da o njoj Evanđelje pripovijeda i da je već trideset ljeta na svijetu nema. Ona mu je odgovorila da je ona Magdalena i da trideset ljeta ondje pokoru čini; da je anđeli sedam puta na nebo uznose da sluša rajske pjesme i rekla mu je da pođe Maksimi$\mathrm{nu}$, da joj tijelo Isusovo (pričest) donese. ${ }^{10}$

Biskup (sveti) Maksimin s mnogim pukom došao je i ugledao Magdalenu dva lakta od zemlje uzdignutu, Boga moleći, te mu reče neka se ne boji pristupiti jer je ona kći njegova. Pričestio ju je, a malo kasnije duh je svoj predala Bogu, a iz tijela se širio ugodan miris. Sveta pokornica umrla je 22. srpnja 84. godine. Sveti Maksimin zapovjedio je da i njega nakon smrti pokopaju pokraj nje. ${ }^{11}$

Na glavi Magdaleninoj i sada se vide dva Isukrstova prsta kojima ju je dotaknuo kad je uskrsnula. ${ }^{12}$

Sveta Marija Magdalena zaštitnica je slave žena, redovnica koje nose njezino ime, pokornica, djece koja teško uče hodati, frizera, učenika i studenata, bačvara i kožara, ljevača olova i rudnika, vinogradara, vrtlara, vincilira ${ }^{13}$, proizvođača parfema i pomada, pomoćnica protiv očnih oboljenja, protiv nevremena i protiv gamadi. ${ }^{14}$

Spomendan Marije Magdalene je 22. srpnja.

\subsection{Sveta Marija Saloma}

Prema predaji Marija Saloma ${ }^{15}$ živjela je u palestinskoj pokrajini Galileji te je poznata i kao Saloma Galilejska. ${ }^{16}$ Tradicija veli da je bila supruga Zebedejeva i majka apostola Ivana i Jakova Starijega. ${ }^{17}$

\footnotetext{
9 Isto.

10 Isto.

11 Isto.

12 Usp. Badurina, nav. dj., 394-395.

13 Vincilir - nadstojnik (čuvar) vinograda. Bratoljub Klaić, Rječnik stranih riječi. Nakladni zavod Matice hrvatske. Zagreb, 1980., 1423.

14 Erhard Gorys, nav. dj., 268.

15 Saloma na hebrejskom znači zdrav, čitav.

16 Sveta Marija Kleofina i Saloma Galilejska (učenice Isusove i majke apostola) https://sveci.net/index.php/component/content/article/2-uncategorised/548sveta-marija-kleofina-i-saloma (pristupljeno 7. srpnja 2019.).

17 Erhard Gorys, nav. dj., 331.
} 
Vjerojatno je i Marija Saloma bila u skupini žena koje su pratile Isusovo djelovanje i propovijedanje. Sigurno je bila uz Isusa na Križnome putu (usp. Mk 15,40) te je bila pod križem na Kalvariji.

Takvu požrtvovnost, u uskrsno jutro, uskrsnuli Krist nagradio je ukazanjem Mariji Salomi, Mariji Magdaleni i Mariji Kleofini, koje su išle k Isusovu grobu. Njih je Isus Krist kao glasnice radosne vijesti poslao tužnim i uplašenim apostolima. Isus se, dakle, ukazao prije pobožnim ženama nego apostolima, čime je svojim učenicima poslao poruku da ne omalovažavaju pobožne vjernice. Marija Magdalena, Marija Saloma i Marija Kleofina pokazale su veću hrabrost od apostola. One su miomirisima htjele pomazati Krista u grobu. Zatekle su prazan Kristov grob te su prve vjesnice Kristova uskrsnuća. Isus ih je pripremio na ukazanje preko svojih anđela. ${ }^{18}$

Pišući o ženama koje su išle u Uskrsno jutro na grob Kristov, sv. Marko Evanđelist, naziva ju Salomom. Sv. Matej Evanđelist spominje ju kao majku sinova Zebedejevih, koja je molila Isusa da u svojem kraljevstvu njezinim sinovima dodijeli počasna mjesta. Teolozi u zamolbi Marije Salome vide sliku Crkve koja moli za svoju djecu. Isus Krist nije izravno odgovorio na tu zamolbu, a teolozi to tumače kako Krist kaže da nema povlastica, nego će u Njegovu kraljevstvu mjesta zauzeti oni koji to zasluže svojim životom i smrću. ${ }^{19}$

Svetu Mariju Salomu štuju posebice u Palestini, u Carigradu, u francuskom Ariesu, u belgijskom Tournaiu i u talijanskim biskupijama Veroliju, Castelliriju i Sori. U svetačkoj ikonografiji veliki umjetnici, kao što su Albreht Dürer i Beato Angelico, prikazuju Mariju Salomu u skupini žena mironosica s posudom mirisne i dragocjene pomasti. ${ }^{20}$

Spomendan sv. Marije Salome je 22. listopada.

\subsection{Sveta Marija Kleofina}

Sveta Marija Kleofina zajedno je s Djevicom Marijom, Marijom Magdalenom i Marijom Salomom pratila Isusa dok su ga vodili na Kalvariju, molila je ispod križa na Kalvariji. Očevidac, sveti Ivan Evanđelist, piše: "Kod Isusova križa stajale su njegova majka i sestra njegove majke, Marija Kleofina i Marija iz Magdale« (Iv 19, 25). Pri tome treba uzeti u obzir da se semitskim izrazom sestra naznačuje bliža rođakinja. Prema evanđeoskim izvorima ona je majka aposto-

18 Sv. Marija Saloma, Katolički tjednik. Sarajevo, 22. listopada 2006.

19 Isto.

20 Isto. 
la Jakova Mlađeg ${ }^{21}$ i Josipa ${ }^{22}$. Marija Kleofina ostala je na Kalvariji i nakon Isusove smrti pribivala je njegovu pokopu, a na uskrsno jutro $\mathrm{s}$ ostalim ženama došla je na grob pomazati Isusovo tijelo.

U nekim izvorima navodi se da je suprug Marije Kleofine bio brat sv. Josipa. ${ }^{23}$ Neki smatraju da je Marijin muž Kleofa bio brat sv. Josipa, a po drugim izvorima Marija Kleofina nije bila jetrva Marije Bogorodice, nego njezina sestrična. ${ }^{24}$

Spomendan sv. Marije Kleofine je 24. travnja.

\section{SVEto VAZMENO TRODNEVLJE}

Sveto vazmeno trodnevlje vrhunac je liturgijske godine, u kojem se obnavlja otajstvo raspetoga, pokopanog i uskrsloga Krista. U hrvatskoj tradicijskoj kulturi koriste se nazivi Sveto trodnevlje i Veliko trodnevlje, a započinje misom Večere Gospodnje na Veliki četvrtak, vrhunac je u Vazmenom bdijenju a završava drugom večernjom na Uskrs. ${ }^{25}$

U hrvatskoj pasionskoj tradicijskoj baštini Sveto trodnevlje karakteriziraju pobožnost, post, četrdesetsatno klanjanje (kvarantore), obredi, običaji, pjesme/molitve. Prema navodima Markova evanđelja spominje se Marija majka Jakova Mlađega i Josipa. Saloma se u kontekstu s Magdalenom spominje u Markovu evanđelju. Očito je da su pjesme o tri Marije nadahnute i s retkom Mk 16,1.

21 Apostol Jakov sin je Alfeja i Marije Kleofine, a zvao se Jakov Alfejev, brat Gospodinov, Jakov Mlađi i Jakov Pravedni, drugi Ivan Krstitelj. Sv. Pavao je Jakova, Petra i Ivana nazvao stupovima Crkve. Jakov je nazivan i Jakov Alfejev svjedočio je Kristovu životu, stradanju, uskrsnuću i uzašašću. Bio je prvi biskup u Jeruzalemu, gdje je 61 . godine podnio mučeništvo.

22 Josip je vjerojatno bio samo Isusov učenik.

23 U nekim izvorima navodi se da je suprug Marije Kleofine bio brat sv. Josipa. Usp. Tko je bila Marija Kleofina, svetica pod križem? https://www.bitno.net/vjera/ svetac-dana/tko-je-bila-marija-kleofina-svetica-pod-krizem/ (pristupljeno 29. rujna 2019.).

24 Sveta Marija Kleofina: Kad su svi pobjegli od Isusove muke, ona je ostala podno križa. https://www.bitno.net/vjera/svetac-dana/sveta-marija-kleofina/ (pristupljeno 29. rujna 2019.).

25 Usp. Marko Babić, Sveto vazmeno trodnevlje. Služba Božja 43 (1). Katolički bogoslovni fakultet Sveučilišta u Splitu, Split, 2003., 71-76. 


\subsection{Veliki četvrtak}

Veliki četvrtak dan je spomena na Isusovu Posljednju večeru ${ }^{26}$, koju je prije muke proslavio sa svojih dvanaest apostola:

(26) I dok su blagovali, uze Isus kruh, izreče blagoslov pa razlomi, dade svojim učenicima i reče: "Uzmite i jedite! Ovo je tijelo moje!" (27) I uze čašu, zahvali i dade im govoreći: "Pijte iz nje svi! (28) Ovo je krv moja, krv Saveza koja se za mnoge prolijeva na otpuštenje grijeha. (29) A kažem vam: ne, neću od sada piti od ovog roda trsova do onoga dana kad ću ga - novoga s vama piti u kraljevstvu Oca svojega." (30) Otpjevavši hvalospjeve, zaputiše se prema Maslinskoj gori. (Mk 14,27-31; Lk 22,31-34; Iv 13,36-38)

Isus je svojim učenicima ostavio trostruki dar: euharistiju misu i pričest, svećenstvo u Crkvi te zapovijed bratske ljubavi. Također, za vrijeme večere Isus Krist je nagovijestio da će ga jedan od apostola izdati i obećao svog Duha protiv duha zla. Isus je svojom krvlju ustanovio novi i vječni savez između Boga i ljudskog roda. Juda Iškariotski otišao je u mrak, predao Učitelja iz Nazareta u smrt za trideset srebrnjaka i od očaja se objesio.

Na taj dan Crkva ulazi u Sveto trodnevlje i sprema se na slavljenje Uskrsa. Poslije pjesme Slava Bogu na visini zavežu se crkvena zvona, čime simbolički započinje simbolički post ušiju. Potom se na kraju slavlja ogoli oltar, što simbolizira početak posta očiju, ili, možemo reći, u pučkoj pobožnosti i početak Kristove muke. ${ }^{27} \mathrm{U}$ mnogim crkvama u Hrvatskoj, Sloveniji i drugim zemljama uredi se Kristov grob, što rade mještani i/ili časne sestre i crkveni službenici. Grob se uređuje cvijećem, proklijalom pšenicom, svijećama. ${ }^{28}$

26 Liturgijska tradicija Zapadne Crkve veže Posljednju večeru uz židovsku Pashu, prema izvještajima sinoptičkih evanđelja (Matej, Marko i Luka). Ivanovo evanđelja ne veže je uz Pashu, nego je naglasak na oproštajnoj večeri Isusa i učenika prije Muke Kristove. Pasha je židovski blagdan u znak zahvalnosti Bogu koji ih je izveo iz egipatskog ropstva. Na taj blagdan Židovi kolju janje ili kozle, tako da im ne slome nijednu kost, te pečeno meso uz beskvasne kruhove i gorko zelje obiteljski obredno blaguju za večeru. Anđelko Badurina, (ur.) Leksikon ikonografije, liturgike i simbolike zapadnog kršćanstva i Uvod u ikonologiju Radovana Ivančevića. Kršćanska sadašnjost. Zagreb, 1990., 450.

27 Ovi postovi završavaju vazmenim bdijenjem: Službom svjetla i službom riječi završavaju post očiju i post ušiju; na simbolički način, igrom simbola, liturgija svijećom navješćuje kraj posta očiju, a čitanjima i zvonjenjem kraj posta ušiju! Usp. Rimski misal, Vazmeno bdijenje.

28 Jasna Čapo Žmegač, Hrvatski uskrsni običaji, Korizmeno-uskrsni običaji hrvatskog puka u prvoj polovici XX. stoljeća, pučka pobožnost, zajednica. Golden marketing. Zagreb, 1997., 34. 
U Ždrelcu na otoku Pašmanu kod Zadra, primjerice, Kristov grob se uređuje proklijalim bijelim grahom ${ }^{29}$ koji je zasađen na početku korizme i rastao je u mraku. Nekoć se u Poljicima kod Imotskoga na Isusov grob stavljalo dvanaest tanjurića proklijale pšenice, a u sredinu svakog tanjurića stavljala se čaša s vodom, uljem i lumini$\mathrm{ma}^{30}$ koji su gorjeli do Velike subote u ponoć. Od Velikoga četvrtaka do Uskrsa Kristov grob čuvaju čuvari. ${ }^{31}$

\subsection{Veliki petak}

Veliki petak spomendan je muke i smrti Isusa Krista. Veliki petak vrhunac je godišnje pokore. To je dan žalosti, kad Crkva propisuje obvezatan post i nemrs. Taj post $\mathrm{u}$ hrvatskoj tradiciji naziva se sušenje, žežinjanje ${ }^{32}$, žinjanje. Nekoć je svatko zasebno molio trideset tri Isusove krunice. Vjeruje se da onaj tko do podne izmoli trideset tri krunice, dobiva potpuni oprost grijeha. Hrvatska je tradicija da se na Veliki petak pomaže bolesnima i siromašnima. Odlazi se u crkve i slijede obredi.

Na Veliki petak ne slavi se euharistijsko slavlje, već se obavljaju obredi Velikog petka. Pjeva se, odnosno (u primorskim župama) kanta Muka Isusova, otkriva se i ljubi križ te se naposljetku dijeli pričest.

Budući su ovi dani najvažniji u liturgijskoj godini, a nerijetko su liturgija i teološko značenje puku bili nerazumljivi, nije neuobičajeno da su se uz njih usporedno s liturgijom pojavljivala različita tumačenja bliža pučkom shvaćanju. Tako možemo naći vrlo rane hrvatske pučke pjesme i molitve s temom pasije, koliko je do sada poznato, iz 14. i 15. stoljeća, a svrha im je vjerojatno katehizacija pobožnoga puka. U 18. stoljeću na pučku su pobožnost snažno utjecala djela Gospin Plač Petra Kneževića i Cvit razlika mirisa

29 Kod drevnih Rimljana grah je bio pokojničko jelo.

30 Lumin, od tal. lumino - žižak, svjećica, dušica, lumin za mrtve.

31 O tome više: Marko Dragić, Čuvari Kristova groba u pasionskoj baštini Hrvata/ Čuvarji Kristusovega groba v hrvaški pasijonski dediščini. Pasijonski almanah (ur. Jože Štukl; Franc Križnar). Škofja Loka, 2017., 53-112.

32 Ieiunum, ii, n. (lat.) post; ieiunus, adi. (lat.) žalostan, gladan. Žežin, žežinjanje - post pred velike blagdane, najčešće jede se samo kruh i pije voda a u nekim krajevima ne jede se ni kruh. 
duhovnoga Tome Babića. ${ }^{33} \mathrm{U}$ tim djelima prepleću se pučka i usmenoknjiževna poetika. ${ }^{34}$

Nekoć se Gospin plač pjevao i tijekom cijele korizme, kako u crkvi, tako i po kućama uvečer. Gospin plač je, današnjim rječnikom rečeno, poema koja jednostavnim i lako pamtljivim izrazima prikazuje Isusovu muku iz perspektive njegove majke, Blažene Djevice Marije. Slično Gospinu plaču pojavljuju se i druge pučke poeme, pjesme koje, opisujući događaje vezane uz trodnevlje, imaju svrhu jednostavnim i razumljivim jezikom puku što više približiti otajstva koja se slave. Nisu liturgija, ali iz same njihove literarne kompozicije razvidno je da ih možemo smatrati paraliturgijom.

Na tom tragu je pučka pjesma u osmercu koja se pjevala u stolačkom kraju na Veliki petak po povratku s obreda:

"Prošetale tri Marije,

tri Marije, tri Djevice.

One traže Sveto groblje,

Sveto groblje Isusovo.

Kad su išle govorile:

'Koja prva grobu dođe,

da odvale s groba stijenu,

da pomaže svete rane,

Svete rane Isusove.

Kad su bile blizu groba,

uspreznule, nesmjernule,

grobu doći.

Kad na grobu mlado sjedi,

sjajnije od sunašca,

jasnije od mjeseca.

Anđeo im s groba veli:

'Kud idete, ne bježite?

Kud idete šta tražite?

'Mi tražimo Sveto groblje,

Sveto groblje Isusovo.

,Vi ga naći i nećete,

33 Početci liturgijske drame sežu u 10. stoljeće, a procvat doživljava već u 12. i 13. st. U Hrvatskoj su te predstave nazivane skazanja ili prikazanja. Prvi tekst pasionske drame Visitati sepulchri (Posjet grobu) datira iz 11. ili 12. st. Hrvojev misal (1404.) i Petrisov zbornik (1468.) svjedoče kako su i glagoljaši njegovali tu dramu.

34 Stipe Botica, Povijest hrvatske usmene književnosti. Školska knjiga. Zagreb, 2013., 221. 
evo danas treći dan je, kad je Isus uskrsnuo.

Pozdravio Petra Pavla, i Ivana Krstitelja.

Da mu oni blagoslove:

Sveto tijelo od pšenice,

Sveto krvce od lozice."

$\mathrm{O}$, Isuse budi hvaljen,

po sve vijeke vijeka Amen. «35

U Slanom je u pamćenju pjesma po kojoj je Ivan evanđelist navijestio Gospi plač jer su joj sina ugrabili. Gospa je odmah ustala i s Ivanom požurila. Začuli su žamor ljudi, ali Isusa nisu vidjeli, nego su vidjeli tri Marije: Mariju Josipovu, Mariju Jakubovu (Jakovljevu) i Mariju Magdalenu:

"Muka Boga Gospodina,

Isukrsta Božjeg sina,

po Ivanu Vanđelisti,

koji Gospi plač navijesti.

5. Gospi Sina ugrabiše,

na križ jom ga propinjaše.

Kad to Gospa poslušala,

ničice je zemlji pala.

10. Kad je Ivo sagledao,

on se Gospi smjerno moli:

'Nemoj Gospe, slavna Gospe,

ako možeš izdržati,

15. svomu srcu žalosnomu.

Prekrijmo se crnim skutom,

potecimo pravim putom

đe se čuje žamor ljudi

da pitamo za Isusa.`

20. Kad je Gospa saslušala,

na noge se ustanula,

pa pođoše dalje putom.

Govor ljudi pristigoše

tu Isusa ne bijaše,

25. neg' bijahu tri Marije,

$35 \quad$ Stolac 2008. 
tri Marije, tri djevice:

Jedna Marija Josipova,

druga Marija Jakubova,

treća Marija Magdalena.

30. Kad ji Gospa sagledaše,

ona ji upitaše:

'Tri Marije, tri sestrice,

viđoste li đe Isusa,

moga sina jedinoga?

35. Njome gospe govorile:

,Djevo Majko, Gospe slavna,

mi smo ti ga i viđele.

Ovuda ga provedoše

u suknenom suknenici.

40. Mi smo njemu govorile:

'Bora tebi, dragi Bože,

jesi l' od roda Davidova?

Isus ništa ne govori,

neg' ničice zemlji gleda.`

Saznavši da je Isus u palači pred Pilatom, Gospa i Ivan uputili su se Pilatu. Isusa su iz palače izveli, teško bičevali i poveli na Kalvariju:

45. Kad to Gospa saslušala,

ničice je zemlji pala.

Kad je Ivo sagledavo,

za ruku je uhitio,

pa se Gospi smjerno moli:

50. 'Nemoj Gospe, slavna Gospe,

ako možeš izdržati

svomu srcu žalosnomu.

Prekrijmo se crnim skutom

pa pođimo pravim putom

55. u palaču u Pilata.ı

Kad su došli u palaču,

tu nađoše svetog Petra

kako stoji na vratima

pa mu Gospa plačom reče:

60. 'Sveti Petre, dragi brate, 
učeniče izabrani, viđe li mi đe Isusa, moga sina predivnoga?

Njome Petar odgovara:

65. 'Djevo Majko, Gospe slavna, ja sam ti ga i vidio, sve sam do sad sa njim bio.

Evo ti ga u palači, u palači kod Pilata.ı

70. Kad to Gospa saslušala, pa je Petru govorila:

,Ti uzmi mač u ruku, pa uđi u palaču, pa udari poglavicu.`

75. Kad je Petar razumio, on uzeo mač u ruku i ušao u palaču, udario poglavicu, pa se nazad povratio.

80. Pa mu Gospa plačom reče:

'Sveti Petre, dragi brate, ti vrati mač u kore i operi bijele ruke da te ne bi globa pala,

85. il' na tebe, il' na ženu.'

Kad je Petar razumio, on ostavi mač na mjesto i oprao bijele ruke.

Iz palače svi Židovi iziđoše

90. i Isusa izvedoše.

Tu ga teško izbičaše.

Narodni pjevač u stihovima 93-97 opisuje susret Jude i Blažene Djevice Marije.

Tada Juda priđe Gospi i dava jom trides dinar pa jom tada govoraše:

95. 'Evo tebi, slavna Gospe! Ja sam tvoga sina prodo. 
Ja sam mu se učinio, tvomu sinu za cesara.'

Gospa Judi govoraše:

100. 'Hajd' odatle, proklet da si!

Neću trides dinara,

neg' Isusa pravednoga,

moga sina jedinoga.ı

U to doba iz palače

105. svi Židovi izlaziše

i Isusa izvedoše.

Tu ga teško izbičaše

i otalen povedoše

na tu goru Kalvariju.

Potresni su stihovi razgovora Djevice Marije i Isusa dok je nosio križ prema Kalvariji. Isus je Majci rekao da joj daje Ivana za sina. Isusa su razapeli, a kada je izdahnuo, skinuli su ga i dali Majci u krilo:

110.Za njim majka pristajaše,

pa Isusa dozivaše:

'Pričekaj me, željo moja,

jadna ti je majka tvoja,

da ti pomožem križ nositi

115. na tu goru Kalvariju,

na ramenu obranjenu.`

Isus ništa ne govori,

neg' ničice zemlji gleda

pa jom zatim progovara:

120. 'Ostav me se, Božja ženo, za ne rijet', majko moja!

Evo tebi Iva sina

dokle mene zaboraviš.ı

A Isusu majka reče:

125. Kako ć' Iva sinom zvati

kad sam tebe porodila?

Idućima Kalvarijom,

Gospa nađe lokvu krvi

pa napaja Iva.

130. 'Zdrav si, Ivo, novi sine,

ovom krvi Isusovom! 
Kalvariji kad dođoše,

tu Isusa propinjaše,

iz Isusa duh izađe.

135. Dadoše ga tužnoj majci, razvila ga po svom krilu.

U to doba sveti Josip, on donio novi pokrov.

U pokrov ga zamotaše,

140.u nov grob ga sahraniše.

Slava tebi, Gospodine,

i na nebu i na zemlji!

Sama Gospa govorila:

145.'Ko ovu molitvu

u korizmi molio,

Gospa mu se smilovala,

prije smrti osam dana.ı

Ovako bi govorila:

150.)Uputi se, rajska dušo,

nećeš duše izgubiti,

bez svjetlosti nećeš biti,

ni bez lica Sina moga.ı 36

Navedena dijaloška molitva nepoznatog je postanja, a iznimno je emotivna, slikovita i puna dramatičnosti.

\subsubsection{Isusov ukop}

Isusov ukop opisuju sva četvorica evanđelista. U kratkim crtama zajednički nazivnik svega jest: u večer kad je bila priprava, ugledni vijećnik Josip iz Arimateje odvažio se, ušao Pilatu i zatražio Isusovo tijelo. Pilat se začudio da je već umro i upitao je satnika je li Isus odavno umro. Kad je Pilat saznao da jest, Isusovo tijelo darovao je Josipu. Josip je kupio platno, skinuo tijelo s križa, zavio ga $\mathrm{u}$ platno te ga položio u grob koji je bio izduben u stijeni. Na grobna vrata dokotrljao je kamen. Marija Magdalena i Marija Kleofina promatrale su kamo Isusa polažu. (Mt 27,57-61; Lk 23,50-56; Iv 19,38-42). I Isusov ukop je dakle jedna od tematskih okvira pučkih pjesama o Tri Marije!

36 Studentica kroatistike na Filozofskom fakultet u Splitu Rebeka Milković zapisala je 2018. godine. Kazao joj je Antun Pavlina iz Slanoga. 


\subsection{Velika subota}

Velika je subota dan Isusova počinka u grobu. Vjernici posjećuju Božji grob. To je dan šutnje i ozbiljnosti mirovanja koje uskrsnim ili vazmenim bdijenjem prelazi u iznenađenje Kristova uskrsnuća.

Veliku subotu narod naziva i Bijelom subotom. ${ }^{37}$ Bila se subota zove tako jer se na taj dan trebalo dobro umivati, pralo se i čistilo. U svim je hrvatskim krajevima na Veliku (Bilu) subotu bio običaj umivanja vodom koja je netom blagoslovljena u crkvama, a ako netko ne bi imao tu vodu, valjalo se umiti na vrelima, potocima, rijekama, moru. U kršćanstvu voda simbolizira pranje, čišćenje i nevinost.

Cijeli se dan čuva Isusov grob, obično se u čuvanju izmjenjuju djeca i mladi. U kreševskom kraju u rano se jutro otvara Isusov grob i čuva do večernje. Tada mladići i djevojke u crkvi pjevaju drugi dio Gospina plača. ${ }^{38}$ I taj dan se posti. ${ }^{39}$

Veliku subotu karakterizirao je obred obnove kućne vatre. U jutro tog dana svećenik je pred crkvom blagoslivljao vatru. Na Veliku subotu palila bi se vatra ispred crkve $^{40}$ i djeca bi u konzervama od kuće do kuće nosila vatru koju je svećenik blagoslovio. Domaćini bi primili vatru, a djeci bi dali šareno jaje i koji novčić. Navečer bi išli u crkvu i vraćali se radosni kući jer je Krist uskrsno i spasio svijet od vječne smrti. ${ }^{41}$

U poljičkom kraju, kod Splita, na Veliku subotu moli se ovako: "Tri Marije gredom gredu, slavnom gorom i maslinom.

Svaka nosi masti i pomasti, čim će Isusu rane trati.

37 Hrvati katolici $\mathrm{u}$ istočnoj Hercegovini (Popovo polje) Bijelu subotu nazivaju Crvenom subotom jer se jaja boje u crvenu boju koja simbolizira Kristovu krv.

38 Augustin Kristić, Crkveno-narodni običaji Kreševa. Sarajevo: posebno otisnut otisak iz "Dobrog pastira", god. VII. Sarajevo, 1956., 17.

39 U nekim krajevima posti se do podne, ništa ne jedući.

40 U hrvatskoj tradicijskoj kulturi uskrsni krijes palio se i u noći s Velike subote na Uskrs ili oko tri-četiri sata pred samu zoru. Taj je običaj bio posebno raširen u sjeverozapadnoj Hrvatskoj. Pastiri su za taj dan pripravljali krjesove budno motreći cijelu noć da im tko ne bi prije vremena potpalio krijes. Garištu iza tih krjesova pripisivala se apotropejska funkcija: preko njega pregonila se stoka kako bi bila zdrava; ugarci sa zgarišta stavljani su u njive i vrtove kako bi plodnost bila bolja; vjerovalo se da vještice i drugi demoni neće imati vlast dokle dopre svjetlost i dim uskrsnih krjesova. Na otoku Ugljanu kod Zadra na nekom većem prostoru sličnom trgu palila se od smilja i suhih drva uskrsna vatra - koleda, koju su momci i djevojke preskakali "u želji za ženidbom, odnosno udajom".

41 U Kreševu 2009. priopćila je gospođa rođ. 1935. 
Poplašile se tri Marije, anđeo im govorio:

„Ne plašite se, tri Marije,

ja znam koga išćete, vi išćete Božjeg sina

i u grobu Spasitelja.

On je uskrsnuo i poručio, svetom Petru i Pavlu i svom bratu Ivanu, da sutra rano u nedilju, prikažu bilo zrnce od pšenice i crno krvce od vodice. ${ }^{42}$

Velik je broj hrvatskih katoličkih vjerskih usmenih lirskih pjesama koje govore o tri Marije. Te su pjesme dijaloške. U Golinjevu 2018. godine kazivačica je priopćila pjesmu:

"Tri su dive Bogu mile,

pa su rano uranile, Božjim putem uputile, jedna drugoj govorile: 'Ko će Božjem grebu doći?

Ko će kamen oboriti?

Ko ce greb taj otvoriti?

Tad iziđe malo dite, u bilini žarkog sunca, pa im lipo progovara:

Ja znam dive šta tražite, vi tražite Božjeg groba i u grobu Isukrsta! Isus Krist je uskrsnio i na nebo uzodio, na nebesim govorio Petru, Pavlu i Ivanu da mu dođu sutra rano, sutra rano u nedilju, da će i nji napojiti, svojom krvi od lozice,

42 U Krušvaru kod Poljica 2006. pripovjedila ju je najmlađa kazivačica u ovom radu, rođ. 1955. 
svoga tila od šenice,

rajskom rikom i vodicom. Amen. « 43

Pšenica simbolizira blagostanje i zemaljsko izobilje, a u euharistiji označava euharistijski kruh. Zrnje žita je euharistijski simbol Kristove ljudske naravi. ${ }^{44}$

U kasnim večernjim satima u crkvama počinje vazmeno bdijenje, majka cijele kršćanske liturgije, koja završava svečanom euharistijom koja označava Kristovu pobjedu nad smrću. U sinjskom kraju u pamćenju je starinska molitva:

"Zvoni, zvoni Glorija,

veseli se Marija!

Tu prođoše tri divice, tri Marije.

Svaka nosi bio bus

i u busu slavnu mast

da će Isusu rane mazat.

Anđel sidi za kamenom,

uplaše se tri divice, tri Marije.

'Ne bojte se, tri divice,

ja znam koga ištete.

Vi ištete Božjeg sina.

Božji sin je uskrsnuo,

na nebesa uzašao.

Poručio Petru, Pavlu

i Ivanu bratu svomu

da mu dođu prikazati

crno krvi od lozice,

bijelo tilce od pšenice. « 45

Sljedeća je vjerska lirska pjesma slikovita i, kao sve druge vjerske pjesme, iznimno emotivna. Tri su Marije krenule preko Kalvarije noseći zlatno puce i u njemu sveto ulje da Isusu mažu rane.

43 Golinjevo kod Livna 2019.

44 Usp. (20) A među onima koji su se došli klanjati na Blagdan bijahu i neki Grci. (21) Oni pristupe Filipu iz Betsaide galilejske pa ga zamole: "Gospodine, htjeli bismo vidjeti Isusa." (22) Filip ode i kaže to Andriji pa Andrija i Filip odu i kažu Isusu. (23) Isus im odgovori: "Došao je čas da se proslavi Sin Čovječji. (24) Zaista, zaista, kažem vam: ako pšenično zrno, pavši na zemlju, ne umre, ostaje samo; ako li umre, donosi obilat rod. (25) Tko ljubi svoj život, izgubit će ga. A tko mrzi svoj život na ovome svijetu, sačuvat će ga za život vječni. (26) Ako mi tko hoće služiti, neka ide za mnom. I gdje sam ja, ondje će biti i moj služitelj. Ako mi tko hoće služiti, počastit će ga moj Otac." (Mt 16,24-25; Mk 8,34-35; Lk 9,23-24.)

45 Zapisano na Gljevu kod Sinja 2016. po kazivanju gospođe rođ. 1942. 
Međutim, dolazi do dramatičnog obrata: susreće ih Pilat i govori im da Isusa neće vidjeti:

"Rano rane tri Marije

priko gore Kalvarije,

jedna od nji' Isusova, druga od nji' Josipova, treća od njiJakovljeva.

One nose zlatno puce

i u puce sveto ulje,

da Isusu mažu rane,

Pilat i' je opazio,

izdaleka potpazio:

'Kud iđete, tri Marije,

kud iđete, kog gledate?

'Mi gledamo Božjeg sina,

Isukrsta Gospodina.'

,Vratite se, tri Marije, priko gore Kalvarije.

Vi ga danas naći nećte, već dođite u nedilju,

u nedilju na blagdanak,

lipo ću vas darovati,

il' bilicom, il' pšenicom,

ili krvi Isusovom.

O Isuse, budi valjen,

Posve vike vikov. Amen." 46

U sličnoj pjesmi tri Marije prošetale su preko gore Kalvarije do Isusova groba. Na grobu su zatekle ditića koji im je rekao rekao da u grobu nema Spasitelja:

"Prošetale tri Marije, priko gore Kalvarije.

Svaka nosi bile puce,

bile puce kano sunce.

U pucama svete maze

kim Isusu rane mažu.

Kad su bile bliže greba, one su se pripanule

$46 \quad$ Rakitno kod Posušja 1997. 
natrag su se uspregnule.

A na grebu ditić sidi.

Ditić njima progovara:

'Ne bojte se, tri Marije,

tri Marije Kalvarije!

Ti, Marijo Šimunova,

ti, Marijo Jozipova,

ti, Marijo Jakovljeva,

kad ja znadem šta tražite:

,Vi tražite Božjeg greba

i u grebu Spasitelja.

Ovdek njega danas nema.

Reko vam je da dojdete

ujtra rano u nedilju.

On će vama oprostiti,

on će vas i darovati

svojom krvcom od ložnice

svojim srcom od krunice.

Amen. « 47

U stolačkom kraju tri divice na Isusovu grobu dočekao je mladić sjajniji od mjeseca, / zlatnijije od sunašca:

"Prošetale tri Divice,

tri Divice, tri sestrice,

sve tri Božje službenice.

Kad su došle blizu groba,

kad na grobu mladić sjedi,

sjajniji je od mjeseca,

zlatniji je od sunašca.

Dive su se ufatile

i sve natrag povraćale.

Progovara mladić s groba:

'Kud idete, tri divice,

tri divice, tri sestrice?

Kud idoste, kog gledaste?

Vi gledate Isukrsta,

Isukrsta Božjeg sina.

47 U Busovači 2007. zapisano po kazivanju gospođe koja kaže da je pjesmu upamtila od svoga oca, rođ. 1910. 
Jutros Isus uskrsnuo,

Na nebesa poletio,

Pozdravio Petra, Pavla

i Ivana vele draga,

da mu duša ne postrada,

da mu tijelo ne propada.

Sine Božji budi faljen,

po sve vijeke vjeka. Amen.«48

U tradicijskoj baštini Vrlike tri su Marije do Isusova groba išle kroz goru Mašljikovu. Na grobu ih je dočekao Ditić sav od sunca posjajio i od sniga pobilio:

"Uputile se tri Marije

kroz tu goru Mašljikovu

pa govoraše:

'Ko bi ovaj kamen snijo,

veliki bi čovik bijo.

Na grobu Ditić leži sav od sunca,

posjaijo i od sniga pobilijo.

Kad su njega ugledale,

još su dalje uspredale.

On je njima govorio:

Ne bižite, ne predajte.

A ja znadem kog tražite,

vi tražite Božjeg sina.

Otišo je i tri riječi ostavio:

prvo krvce i lozice,

drugo tijelo i pšenice,

treće sam svoje. Amen.«49

U Okrugu Gornjem kod Trogira staroga je postanja pjesme o tri Marije koje idu uz goru Maslovine da pomažu Isusove rane. Pred njima se pojavio anđeo.

Tri Marije redun gredu,

už nu goru Maslovine.

Svaka nosi struk masline,

za pomazat slavne rane,

48 Don Mato Puljić, Stolac. Prema Marčinkuši iz Ćorića, a ona 1988. čula od svoje majke koja je s Previši.

49 Vrlika 2011. 
slavne rane Isusove.

Jedan anđel upadoše, a one se prepadoše:

"Ne bojte se, tri divice, vi ste moje posestrice. Vi ste kora anđeoska, i korata nebeskoga.

Ajte gori svi u raj, di anđeli svi igraju. Meju njima tri-četiri, Īsusovi kančelari ${ }^{50}$.

Sveti Ivan prve vrsti, koj Isusa vodun krsti. "51

U Dolu na Hvaru starinska je molitva o tri Djevice koje su Isusu nosile, žij ${ }^{52}$, slavne masti i bijeli šudar:

"Redom gredu tri Marije, tri divice, svaka nosi dar Isusu. Jedna nosi žij pribili, druga nosi šudar bili, treća nosi slavne masti, za Isusu rane mazati. Kad su došli srid gorice, na kameni suđel ${ }^{53}$ staše i njima govoraše:

'Di gret tri Marije, tri divice?

Znom koga išćete, Isusa Nazarećanina.

Nema ga, uskrsnuo je, kako je rekao Petru i Pavlu i Ivanu svom dragu, da će doći uzneseno, na uznesenju,

50 Kančelar - kancelar.

51 Pjesmu je Manuela Bareta Buličić čula od tete Anke Kuzmanić, kćerke njezine pokojne babe Matije Barete. U Okrugu Gornjem kod Trogira zapisala je 2017. godine Jelena Miše.

$52 \check{Z}_{\mathrm{ij}}$ - ljiljan.

53 Suđel - sveti anđeo. 
po sve vjeke vjekova.

Amen.« 54

Ista kazivačica u Dolu na Hvaru kazala je i sljedeću molitvu:

"Tri Marije rijedom grijedu,

svaka nosi dar Isusu.

Jedna nosi žij pribili,

druga nosi šudar bili,

treća nosi slavne mosti,

za Isusu rane mazat.

Kad su došli srid gorice,

na kamenu anđel staše

i njima govoraše:

'Di grjete tri Marije,

tri divice,

znam koga išćete,

Isusa Nazarećanina.

Uskrsnu je kako je rekao,

Petru i Povlu i Ivanu,

sinku dragu,

da će doći na uzmena,

na uzmena, na blažena,

Bog, po sve vijeke vjekova.

Amen. «55

U Dugopolju kod Splita na Veliku subotu moli se molitva u kojoj tri Marije gredom gredu slavnom gorom i maslinom noseći masti i pomasti:

"Tri Marije gredom gredu,

slavnom gorom i maslinom.

Svaka nosi masti i pomasti

čim će Isusu rane trati.

Poplašile se tri Marije,

anđeo im govorio:

'Ne plašite se, tri Marije,

ja znam kog išćete,

54 Ana Roić zapisala je u Dolu na Hvaru 2012. Kazala joj je Margarita Roić, djev. Milatić, 1921. Ana Roić Hvarska duhovnost u suvremenoj etnografiji. (Diplomski rad.) Filozofski fakultet Sveučilišta u Splitu. Split, 2012., 32-33.

55 Ana Roić, nav. dj., 13. 
vi išćete Božjeg sina

i u grobu Spasitelja.

On je uskrsnuo i poručuje

Svetom Petru i Pavlu

i svon bratu Ivanu;

da sutra rano u nedilju

prikažu bilo zrnce od pšenice

i crno krvce od vodice! « 56

U Vinjanima Gornjim kod Imotskoga tri dive Božjim putem upućene došle su do Isusova greba i one kamen oborile s groba. Tada je izišlo malo dite žarka sunca, žarka sunca od miseca:

"Tri su dive Bogu mile,

Božjin puten upućene,

među sebon govorile:

'Ko će biti kontra greblja,

ko će kamen oboriti?"«

One biše kontra greblja,

one kamen oboriše.

Kad izađe malo dite,

malo dite žarka sunca,

žarka sunca od miseca.

,I ja znaden šta želite.

Vi želite Božjeg sina,

Isukrsta Gospodina,

što je sinoć uskrsnio,

na nebesa uzlazio,

Petru, Pavlu govorio:

Ko ovu molitvicu bude molio,

jutrom rano, večer kasno,

Blažena će ga Divica prikazati,

prije smrti na petnest dana:

Ispovidi se, moj grišniče,

putuj, moj putniče,

duša ti je spašena i saranjena. « $\$ 77$

Zadnja tri stiha navedene molitve imaju elemente prenja. ${ }^{58}$

56 U Dugopolju 2009. priopćila je umirovljenica rođ. 1939.

57 U Vinjanima Gornjim 2009. priopćila kazivačica rođ. 1923.

58 Prenje je usmenoknjiževni žanr moralno-didaktičkoga dijaloškoga (pretežito) vjerskoga karaktera, a poznavale su ga najstarije civilizacije: sumerska, babilonsko- 
U nekim molitvama narodni pjevač tri Marije naziva sestrenicama. One su tražile sveti grobak noseći bijeli busak i u busku svete masti. Kad su bile blizu groba, na grobu je sjedilo mlado sjajnije od mjeseca, zlatnije od sunašca:

"Prošetale tri Marije,

tri Marije sestrenice,

onom gorom i maslinom,

one traže sveti grobak,

one nose bijeli busak

i u busku svete masti,

čim se mažu svete rane.

Kad su bile blizu groba,

kad na grobu mlado sjedi,

sjajnije je od mjeseca,

zlatnije je od sunašca.

Sve tri natrag pobjegnule.

Progovara s groba mlado:

¿Šta tražite, tri Marije,

tri Marije sestrenice?

Vi ga tražit nemojte,

vi ga naći ne ćete!

Evo danas treći danak,

da je Isus uskrsnuo,

na nebesa odlazio,

izlazio, pozdravio,

Petra, Pavla i Ivana, vele draga,

da mu tijelo blagoslovi,

sveto tijelo od šenice,

slavna krvca od vodice.

Amen Jezus. «59

Kazivačica rođ. 1934. godine u selu Broćanac, župa Gradac, kazala je 2010. godine da je navedena molitva stara 400 godina.

U Komiži na Visu tradicionalna je molitva u kojoj tri divice idu svetom gorom Maslinovom i nose slavne masti kojima cee mazati

asirska (akadska) i staroegipatska. U usmenoj su komunikaciji prenja poznata i u antičkoj grčkoj i rimskoj književnosti, staroj hebrejskoj te u srednjovjekovnoj i novovjekovnoj svjetskoj književnosti.

59 U selu Broćanac, župa Gradac kod Neuma, zapisano 2009., a priopćila je kazivačica rođ. 1934. 
slavne rane Isusove. Kad su došle do Isusova groba na kamenu su vidjele anđela koji im je rekao da je Isus uskrsnuo:

"Tri Divice gorun gredu, svetun gorun Maslinicun. Jedna nosi kriz masline, druga nosi slovne mosti, cin će mazat slovne rane, slovne rane Isusove.

Treća nosi bil sudorić, za otirot slovni obroz, slovni obroz Isusov. Malo puta ucinili, tu nahodu kamin bili. na kamenu sidi onđel. Tri se dive pristrasise, a onđel im odgovoro: 'Ne stroste se, tri divice, vi ste Bozje tri sestrice. Jo vec znoden co isćete! Vi isćete Bozjeg greba i u grebu Bozjeg Sina! Ne isćite Bozjeg greba, ni u grebu Bozjeg Sina. naći Njega vi nećete! Danas vam je treći danak, da je uskarsal na nebesa! Preporucte Petru i Pavlu i Ivanu Karstiteju neka dojdu sutra rano, sutra rano u nediju.

Dat će njima svoga tila, svoga tila od senice, svoje karvi od lozice, a iz raja rojske vode i Svetog Oca blagoslova. « 60

60 Kazivač rođ. 1931. priopćio u Komiži na Visu 2008. 


\subsection{Ophod}

U starini je u iločkom kraju na Veliku subotu postojao običaj da tri žene u tišini odlaze do tri križa. Nisu razgovarale među sobom niti sa slučajnim prolaznicima, već su u sebi molile krunicu i druge molitve. Kod trećeg križa pred crkvom u tišini bi se razilazile svojim kućama. Taj je običaj spomen na tri Marije koje su pratile Isusa od početka Muke do ukopa. Za ove žene reklo bi se da idu tražiti Isusa. ${ }^{61}$

\section{USKRSNO JUTRO}

Uskrs je najveći kršćanski blagdan jer je Isus Krist svojim uskrsnućem spasio i otkupio svijet. Prvotno se Uskrs slavio svake nedjelje, a od 2. stoljeća slavi se jedanput godišnje, nakon prvog proljetnog uštapa, punog Mjeseca, između 21. ožujka i 25. travnja. Podrijetlo mu je u židovskom blagdanu Pashe. Židovi su Pashom slavili čudesna Božja djela koja je on pokazao, posebno izlaskom Izraelaca iz egipatskog ropstva. Kršćanska se vjera usredotočuje na Isusovo uskrsnuće, odnosno prijelaz iz smrti u život.

\subsection{Isusovo uskrsnuce}

Kad je prošla subota, Marija Magdalena i Marija Jakovljeva i Marija Saloma kupile su miomirisa da odu pomazati Isusa. Veoma rano, o izlasku sunčevu, došle su na grob razgovarajući:

Tko će nam otkotrljati kamen s vrata grobnih?« Pogledale su, a kamen koji je bio dosta velik je bio otkotrljan. Kad se ušle u grob, ugledale su mladića zaogrnuta bijelom haljinom koji je sjedio zdesna. Tri Marije su se preplašile a mladić im je odgovorio: "Ne plašite se! Isusa tražite, Nazarećanina, Raspetoga? Uskrsnu! Nije ovdje! Evo mjesta kamo ga položiše. (7) Nego idite, recite njegovim učenicima i Petru: Ide pred vama u Galileju! Ondje ćete ga vidjeti, kamo vam reče!» (8) One iziđu i stanu bježati od groba: spopade ih strah i trepet. I nikomu ništa ne rekoše jer se bojahu. (Mt 28,1-8; Lk 24,1-12; Iv 20,1-10)

Prema Markovu i Ivanovu evanđelju kad su Marije došle pogledati grob, nastao je žestok potres jer je anđeo Gospodnji sišao s neba, pristupio i otkotrljao kamen i sjeo na nj. Lice mu je bilo kao

61 U Iloku zapisano 2008. po kazivanju gospođe rođ. 1943. 
munja, a odjeća bijela kao snijeg. Pred njim su stražari zadrhtali i obamrli. Anđeo je progovorio ženama:

"Vi se ne bojte! Ta znam: Isusa Raspetoga tražite! (6) Nije ovdje! Uskrsnu kako reče. Hajde, vidite mjesto gdje je ležao (7) pa pođite žurno i javite njegovim učenicima da uskrsnu od mrtvih. I evo, ide pred vama u Galileju. Ondje ćete ga vidjeti. Evo, rekoh vam." (Mk 16,1-8; Lk 24,1-12; Iv 20,1-10)

Tri svete Marije žurno su radosne i sretne od groba otrčale javiti Isusovim učenicima:

(9) Kad eto im Isusa u susret! Reče im: "Zdravo!" One polete k njemu, obujme mu noge i ničice mu se poklone. (10) Tada im Isus reče: "Ne bojte se! Idite, javite mojoj braći da pođu u Galileju! Ondje će me vidjeti!“ (Mk 16,1-8; Lk 24,1-12; Iv 20,1-10)

\subsection{Prazan Isusov grob}

Marija Magdalena otrčala je do Šimuna Petra i Ivana kojega je Isus posebno volio, pa im je rekla: "Uzeše Gospodina iz groba i ne znamo gdje ga staviše."

Petar i Ivan se upute i trčeći dođoše se na grob. Ivan je prestigao Petra i prvi stigao na grob. Sagnuo se i opazio povoje gdje leže, ali nije ušao u grob. Ubrzo je stigao i Šimun i za Ivanom ušao u grob. (...) Ugledali su povoje gdje leže:

(7) (...) i ubrus koji bijaše na glavi Isusovoj, ali nije bio uz povoje, nego napose svijen na jednome mjestu. (8) Tada uđe i onaj drugi učenik koji prvi stiže na grob i vidje i povjerova. (9) Jer oni još ne upoznaše Pisma da Isus treba da ustane od mrtvih. (10) Potom se učenici vratiše kući. (Mt 28,1-8; Mk 16,1-8; Lk 24, 1-12)

\subsection{Isus se ukazao Mariji Magdaleni}

Kad je obavijestila apostole Petra i Ivana, Marija Magdalena se vratila grobu, stala je pred grobom i plakala. Plačući, sagnula se prema grobu i vidjela dva anđela, jednoga uz mjesto gdje je ležala Isusova glava, a drugoga uz mjesto gdje su bile Isusove noge. Anđeli su je pitali: "Ženo, zašto plačeš?» Odgovorila im je: "Uzeše Gospodina mojega i ne znam gdje ga staviše." Kad je to izgovorila, okrenula se i ugledala Isusa gdje stoji, ali nije vjerovala da je to Isus. Isus joj je rekao: "Ženo, zašto plačeš? Koga tražiš? " Marija Magdalena je mislila da je to vrtlar pa mu je rekla: "Gospodine, ako si ga ti odnio, 
reci mi gdje si ga stavio i ja ću ga uzeti." Isus je rekao: "Marijo!" Ona se okrenula te mu hebrejskim jezikom rekla: "Rabbuni!" - što znači: "Učitelju!" "(17) Kaže joj Isus: "Ne zadržavaj se sa mnom jer još ne uziđoh Ocu, nego idi mojoj braći i javi im: Uzlazim Ocu svomu i Ocu vašemu, Bogu svomu i Bogu vašemu." (18) Ode dakle Marija Magdalena i navijesti učenicima: "Vidjela sam Gospodina i on mi je to rekao." (Mt 28,9-10; Mk 16,9-11)

Marija Magdalena otišla je javiti učenicima "kako je vidjela Gospoda i što joj je rekao, ali joj oni nisu vjerovali». ${ }^{62}$

U nedjelju, kad je Isus uskrsnuo, u Čaporicama kod Sinja molilo se:

"Tri Marije goron grede,

slavnom goron Maslinovon.

Svaka nosi bija bus

i u busu masti, pomasti,

čin će Isusu rane trati.

'Ne plašte se, tri Marije,

tri Marje, tri divice,

Isus van je uskrsa,

na nebesa uzaša!«63

Velik je broj hrvatske kulturne baštine zauvijek prekrila zemlja. Neki primjeri te baštine fragmentarno su sačuvani. Takav je i navedeni primjer molitve u kojoj su nakon petoga stiha zaboravljeni stihovi.

\section{ZAKLJUČAK}

Tri Marije su s Djevicom Marijom i drugim ženama i muškarcima pratile Isusa od Pilatove palače gdje je Isus osuđen, bičevan, ponižavan. Potom su mu dali nositi križ do Kalvarije, gdje je razapet. Tri Marije i Djevica Marija stajale su pod križem. Dramatične su pjesme i molitve koje hrvatski katolički puk pamti i kazuje. Tri svete Marije pokazale su da su hrabrije od muškaraca. Naziva ih se i mironosnicama, jer su nosile miru (mirhu, dragomast, izmirnu) da pomažu Isusovo tijelo.

Isus Krist je, riječima upućenim Ivanu evanđelistu, u posljednjim trenutcima pokazao kako se vrši četvrta Božja zapovijed o poštivanju roditelja i brizi za njih.

62 Usp. Janko Oberški, nav. dj., 200.

63 Čaporice kod Sinja 2009. 
Kada je Isus izdahnuo, krvnici su ga, prema tradicijskim pjesmama, dali Majci Mariji u krilo. Ugledni vijećnik Josip iz Arimateje ušao je Pilatu i zatražio Isusovo tijelo. Pilat je Isusovo tijelo darovao Josipu. Josip je kupio pokrov, povio Isusa u platno te ga položio u grob koji je bio izdubljen u stijeni.

Tri Marije su u subotu krenule na grob noseći masti i pomasti kako bi Isusove rane namazale. Međutim grob je bio prazan. Isus je uskrsnuo. Isus se, dakle, ukazao pobožnim ženama prije nego apostolima, čime je svojim učenicima poslao poruku da ne omalovažavaju pobožne vjernice.

Nekoliko navedenih pjesama i molitava ima antologijsku vrijednost. No sve je manje onih koji pamte tradicijske pasionske pjesme i molitve. Mnogi primjeri pali su u zaborav, a neki su sačuvani fragmentarno. Stoga je civilizacijski čin sačuvati što se još dade sačuvati o pasionskoj i svoj ostaloj nematerijalnoj kulturnoj baštini.

THREE HOLY MARYS IN CROATIAN PASSION FOLK LITERATURE

\section{Abstract}

The paper cites and interprets about twenty traditional passion poems, prayers and customs within which these poems are told, and speak of Mary Magdalene, Mary of Jacob and Mary Salome who accompanied the Blessed Virgin Mary, together followed Jesus to Golgotha and stood by him when he was crucified. As soon as the Sabbath passed, they bought perfumes with intention to anoint Jesus in his tomb. On their way to the tomb they discussed among themselves who was going to move a great stone from the tomb entrance so they would be able to anoint Jesus. When they approached the grave, they saw that the stone had been moved and the tomb was empty. Upon entering the tomb, they saw a young man dressed in white who sat to the right. They were afraid, but angel (the young man) told them there was no need to be frightened because Jesus was resurrected. He also told them to go to Jesus' disciples Peter and John and to tell them that Jesus was on his way to Galilee where they would be able to see him. Marys were frightened, so they ran away from the tomb to Peter and John and informed them that Jesus was resurrected. When Mary Magdalene informed Peter and John, she went back to the tomb and there Jesus Christ appeared to her. 
The poems in the paper are interpreted in context of the Gospels and the liturgy, as well as in the ethnological and anthropological context. These poems were recorded for the last 22 years in the Republic of Croatia and in Bosnia and Herzegovina. All the poems have a considerable aesthetical meaning and are in agreement with the Gospels. Alongside the poems, the three Marys procession, recorded in Ilok, is mentioned.

Key words: Mary Magdalen, Mary Salome, Mary of Cleopas, the passion of Jesus Christ, Virgin Mary, resurrection, Jesus Christ's tomb. 